\title{
THE EFFECT OF MILD EXERCISE IN THE SUPINE POSITION ON THE PULMONARY ARTERIAL PRESSURE OF FIVE NORMAL HUMAN SUBJECTS ${ }^{1}$
}

\author{
By N. B. SLONIM, A. RAVIN, O. J. BALCHUM, AND S. H. DRESSLER \\ (From the Cardiopulmonary Laboratory of the National Jewish Hospital at Denver and the \\ Department of Physiology of the University of Colorado Medical Center, Denver, Colo.)
}

(Submitted for publication February 10, 1954; accepted March 22, 1954)

In the course of study of a series of patients with cardiopulmonary diseases of various type and degree, it was noted that the pulmonary arterial pressure rose during supine exercise in all instances. This rise was observed even in individuals with minimal pulmonary involvement and no detectable cardiac abnormality. Inasmuch as it has been stated that the pulmonary arterial pressure does not rise appreciably with mild exercise in subjects with normal cardiorespiratory systems (1-3), it seemed necessary to re-examine this question.

It is the purpose of this paper to describe in detail the pulmonary arterial pressure rise which occurs in normal man during mild, supine exercise, together with certain associated physiological changes.

\section{METHODS}

Five untrained individuals were selected for study (Table I). All were considered to be entirely healthy by the criteria of history, physical examination, electrocardiogram, and postero-anterior 6 foot chest roentgenogram.

The subjects were given .09 gram of Nembutal orally the evening prior to catheterization. The morning of the catheterization they were again given .09 gram of Nembutalit orally, and arrived at the laboratory one hour later in the fasting state. Pulmonary artery catheterization was performed in the usual manner (4). An indwelling intra-arterial needle was introduced into the brachial artery on the opposite side. All studies were carried out with the subject in the supine position.

The resting cardiac output was then determined by collection of 6 minute expired gas samples in 100 liter Davol Douglas-Type Gas Bags and withdrawal of simultaneous blood samples from the pulmonary artery and brachial artery. The subjects were then prepared to use an apparatus designed for exercising in the supine position (5). (They had, in each instance, been familiarized with the use of the device on the day before.) Exercise stroke length was 12 inches, but actual excursion of the weight was 6 inches because of the pulley arrangement. A

1 Aided by a grant from the Life Insurance Medical Research Fund. metronome was used to maintain rhythm. Continuous recording of the pulmonary arterial pressure-pulse contours and the pulmonary arterial mean pressure was then begun. While continuous pressure records were being made, the patient began to exercise, moving both lower extremities synchronously. After a warm-up period of 3 minutes, expired gas was collected from 3 to $41 / 4$ minutes (designated 3.6 minutes of exercise) together with blood samples for determination of the cardiac output. Pressure recording was then resumed. At 6 minutes another collection of expired gas was begun, lasting until 71/4 minutes (designated 6.6 minutes of exercise). Exercise was then abruptly terminated. Total exercise time was $71 / 4$ minutes in each instance. Continuous post-exercise recordings of the pulmonary arterial pressure were made for 5 minutes.

The pressure-pulse contours were recorded with a Hathaway Blood Pressure Control Unit and Oscillograph. ${ }^{2}$ The pulmonary arterial mean pressure was detected by means of a Sanborn Electromanometer and recorded by the Hathaway Oscillograph. Recordings were calibrated with a mercury manometer after each tracing. The zero point for all pressures was $5 \mathrm{~cm}$. posterior to the sternal angle of Louis with the patient supine. The pulmonary arterial mean pressure as given by the Sanborn Electromanometer was compared in each instance with the mean pressure obtained by planimetric integration of the Hathaway pressure-pulse contours and found to check within 1 or $2 \mathrm{~mm}$. Hg. All pulmonary arterial mean pressures given in this paper were detected with the Sanborn Electromanometer. Systolic and diastolic pulmonary arterial pressures were obtained by averaging the values for one or more complete respiratory cycles. Measurements of all pressure tracings were rounded to the nearest integer, five-tenths having been rounded to the nearest even integer.

Blood samples were analyzed for oxygen content and capacity by the Scholander-Roughton syringe method (6). Expired gas volume was measured by means of a Precision Wet Test Gas Meter. Expired gas samples were analyzed for carbon dioxide and oxygen content ${ }^{3}$

2 Type SYBP-1 Blood Pressure Recording System.

8 Subsequent to this study it was found that the expired gas had been permitted to remain in the Davol DouglasType Bags too long before analysis. The oxygen uptake and cardiac output data recorded in this paper have been corrected by the application of formulas derived from 
TABLE I

Five normal human subjects and their work rates

\begin{tabular}{|c|c|c|c|c|c|c|c|c|}
\hline Subject & Age & Sex & $\begin{array}{c}\text { Weight } \\
(l b .)\end{array}$ & $\begin{array}{c}\text { Height } \\
\text { (in.) }\end{array}$ & $\begin{array}{c}\text { Body } \\
\text { surface } \\
\text { area } \\
\text { (sq. m.) }\end{array}$ & $\begin{array}{c}\text { A-P } \\
\text { chest } \\
\text { diameter } \\
(\mathrm{cm} .)^{*}\end{array}$ & $\begin{array}{c}\text { Strokes } \\
\text { per } \\
\text { minute }\end{array}$ & $\begin{array}{c}\text { Work } \\
\text { rate } \\
\text { (ft-lb/min.) }\end{array}$ \\
\hline $\begin{array}{l}\text { MJB } \\
\text { MM } \\
\text { MMH } \\
\text { ELM } \\
\text { MES } \\
\text { AVG }\end{array}$ & $\begin{array}{l}20 \\
24 \\
22 \\
25 \\
21\end{array}$ & $\begin{array}{l}\mathbf{M} \\
\mathbf{M} \\
\mathbf{F} \\
\mathbf{F} \\
\mathbf{F}\end{array}$ & $\begin{array}{l}160 \\
150 \\
103 \\
118 \\
118\end{array}$ & $\begin{array}{l}71 \\
70 \\
62 \\
65 \\
62\end{array}$ & $\begin{array}{l}1.91 \\
1.83 \\
1.43 \\
1.58 \\
1.52\end{array}$ & $\begin{array}{l}21 \\
21 \\
18 \\
17.5 \\
14.5\end{array}$ & $\begin{array}{l}28 \\
30 \\
28 \\
25 \\
29 \\
28\end{array}$ & $\begin{array}{l}784 \\
840 \\
784 \\
700 \\
812 \\
784\end{array}$ \\
\hline
\end{tabular}

* Some investigators working in this field record "zero" pressure in the supine subject at the level $5 \mathrm{~cm}$. posterior to the anterior chest wall, while others use the level $10 \mathrm{~cm}$. anterior to the posterior chest wall. Inasmuch as the A-P chest diameter is usually not $15 \mathrm{~cm}$., it is obvious that these levels are not exactly equivalent. Pressure differences resulting from this discrepancy may amount to as much as $5 \mathrm{~mm}$. $\mathbf{H g}$.

with the Scholander micrometer gas analyzer (8). Oxygen uptake was calculated from the results of analysis of expired gas by means of the standard formula (9). All gas volumes including those for oxygen uptake and min-

experimental analysis of the rates of change of carbon dioxide and oxygen concentration in samples of gas permitted to stand in these bags (7). After derivation, these formulas were tested and it was found possible to predict initial gas concentrations from final gas concentrations within the limits of analytical error, when the elapsed time is accurately known. It is therefore felt that the oxygen uptake and cardiac output data given in this paper are quite accurate, and that the above-mentioned error in technique does not invalidate the conclusions drawn from these data. ute volume of breathing were converted to STPD $\left(0^{\circ} \mathrm{C}\right.$., $760 \mathrm{~mm} . \mathrm{Hg}$, dry) and are given as such in this paper. The ventilation equivalents were obtained by dividing the minute volume of breathing (STPD) by the corresponding oxygen uptake (STPD). Cardiac output was calculated using the Fick principle.

\section{RESULTS}

\section{Pulmonary arterial pressure}

The resting pulmonary arterial systolic, mean and diastolic pressures varied from 17 to 26,11 to 17 , and 8 to $12 \mathrm{~mm}$. $\mathrm{Hg}$, respectively (Table II). The average resting systolic, mean, and

TABLE II

The effect of exercise on the pulmonary arterial pressure

\begin{tabular}{|c|c|c|c|c|c|c|c|c|c|c|c|c|c|c|c|c|c|c|}
\hline \multirow{2}{*}{\multicolumn{2}{|c|}{ Subject }} & & \multirow{3}{*}{$\begin{array}{c}\text { Rest } \\
22 \\
12 \\
16\end{array}$} & \multicolumn{9}{|c|}{ Exercise* } & \multicolumn{6}{|c|}{ Post-exercise* } \\
\hline & & & & $z$ & 1 & 3 & 1 & $1\}$ & 2 & 3 & 5 & 6 & $t$ & 3 & 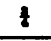 & 1 & 3 & 5 \\
\hline \multirow{6}{*}{ 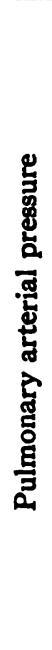 } & MJB & $\begin{array}{l}\mathbf{S} \\
\mathbf{D} \\
\mathbf{M}\end{array}$ & & $\begin{array}{l}27 \\
16 \\
21\end{array}$ & $\begin{array}{l}28 \\
16 \\
21\end{array}$ & $\begin{array}{l}28 \\
16 \\
22\end{array}$ & $\begin{array}{l}28 \\
17 \\
22\end{array}$ & $\begin{array}{l}28 \\
17 \\
22\end{array}$ & $\begin{array}{l}27 \\
16 \\
22\end{array}$ & $\begin{array}{l}27 \\
16 \\
22\end{array}$ & $\begin{array}{l}28 \\
16 \\
22\end{array}$ & $\begin{array}{l}27 \\
16 \\
22\end{array}$ & $\begin{array}{l}22 \\
12 \\
16\end{array}$ & $\begin{array}{l}19 \\
11 \\
14\end{array}$ & $\begin{array}{r}19 \\
8 \\
13\end{array}$ & $\begin{array}{r}17 \\
8 \\
13\end{array}$ & $\begin{array}{r}18 \\
9 \\
13\end{array}$ & $\begin{array}{l}18 \\
10 \\
13\end{array}$ \\
\hline & $\mathbf{M M}$ & $\begin{array}{l}\mathbf{S} \\
\mathbf{D} \\
\mathbf{M}\end{array}$ & $\begin{array}{r}22 \\
8 \\
14\end{array}$ & $\begin{array}{l}24 \\
11 \\
18\end{array}$ & $\begin{array}{l}24 \\
12 \\
19\end{array}$ & $\begin{array}{l}25 \\
12 \\
20\end{array}$ & $\begin{array}{l}26 \\
12 \\
20\end{array}$ & $\begin{array}{l}25 \\
12 \\
19\end{array}$ & $\begin{array}{l}26 \\
12 \\
20\end{array}$ & $\begin{array}{l}27 \\
12 \\
20\end{array}$ & $\begin{array}{l}27 \\
12 \\
20\end{array}$ & $\begin{array}{l}27 \\
12 \\
20\end{array}$ & $\begin{array}{r}23 \\
8 \\
16\end{array}$ & $\begin{array}{r}22 \\
8 \\
16\end{array}$ & $\begin{array}{r}22 \\
9 \\
16\end{array}$ & $\begin{array}{r}21 \\
8 \\
16\end{array}$ & $\begin{array}{r}18 \\
7 \\
13\end{array}$ & $\begin{array}{r}17 \\
6 \\
13\end{array}$ \\
\hline & $\mathbf{M M H}$ & $\begin{array}{l}\mathbf{S} \\
\mathbf{D} \\
\mathbf{M}\end{array}$ & $\begin{array}{l}23 \\
10 \\
15\end{array}$ & $\begin{array}{l}28 \\
14 \\
18\end{array}$ & $\begin{array}{l}29 \\
14 \\
19\end{array}$ & $\begin{array}{l}31 \\
14 \\
20\end{array}$ & $\begin{array}{l}32 \\
14 \\
20\end{array}$ & $\begin{array}{l}32 \\
15 \\
20\end{array}$ & $\begin{array}{l}33 \\
15 \\
21\end{array}$ & $\begin{array}{l}33 \\
15 \\
21\end{array}$ & $\begin{array}{l}28 \\
10 \\
17\end{array}$ & $\begin{array}{l}28 \\
10 \\
17\end{array}$ & $\begin{array}{r}23 \\
6 \\
13\end{array}$ & $\begin{array}{r}23 \\
6 \\
13\end{array}$ & $\begin{array}{r}21 \\
5 \\
12\end{array}$ & $\begin{array}{r}19 \\
5 \\
10\end{array}$ & $\begin{array}{r}18 \\
5 \\
10\end{array}$ & $\begin{array}{r}18 \\
5 \\
10\end{array}$ \\
\hline & ELM & $\begin{array}{l}\mathbf{S} \\
\mathbf{D}\end{array}$ & $\begin{array}{r}17 \\
8 \\
11\end{array}$ & $\begin{array}{l}19 \\
10 \\
14\end{array}$ & $\begin{array}{l}20 \\
10 \\
14\end{array}$ & $\begin{array}{l}21 \\
11 \\
15\end{array}$ & $\begin{array}{l}23 \\
12 \\
16\end{array}$ & $\begin{array}{l}22 \\
11 \\
16\end{array}$ & $\begin{array}{l}23 \\
12 \\
17\end{array}$ & $\begin{array}{l}22 \\
12 \\
16\end{array}$ & $\begin{array}{l}21 \\
11 \\
15\end{array}$ & $\begin{array}{l}21 \\
11 \\
15\end{array}$ & $\begin{array}{r}20 \\
8 \\
12\end{array}$ & $\begin{array}{r}20 \\
7 \\
11\end{array}$ & $\begin{array}{r}19 \\
7 \\
10\end{array}$ & $\begin{array}{r}19 \\
7 \\
10\end{array}$ & $\begin{array}{r}19 \\
7 \\
10\end{array}$ & $\begin{array}{r}19 \\
7 \\
10\end{array}$ \\
\hline & MES & $\begin{array}{l}\mathbf{S} \\
\mathbf{D} \\
\mathbf{M}\end{array}$ & $\begin{array}{l}26 \\
10 \\
17\end{array}$ & $\begin{array}{l}31 \\
14 \\
21\end{array}$ & $\begin{array}{l}31 \\
13 \\
21\end{array}$ & $\begin{array}{l}29 \\
12 \\
20\end{array}$ & $\begin{array}{l}29 \\
12 \\
19\end{array}$ & $\begin{array}{l}28 \\
12 \\
18\end{array}$ & $\begin{array}{l}28 \\
13 \\
18\end{array}$ & $\begin{array}{l}26 \\
14 \\
18\end{array}$ & $\begin{array}{l}26 \\
13 \\
18\end{array}$ & $\begin{array}{l}26 \\
13 \\
18\end{array}$ & $\begin{array}{l}26 \\
13 \\
18\end{array}$ & $\begin{array}{l}26 \\
12 \\
17\end{array}$ & $\begin{array}{l}26 \\
12 \\
17\end{array}$ & $\begin{array}{r}24 \\
9 \\
15\end{array}$ & $\begin{array}{r}24 \\
9 \\
15\end{array}$ & $\begin{array}{r}24 \\
9 \\
15\end{array}$ \\
\hline & AVG & $\begin{array}{l}\mathbf{S} \\
\mathbf{D} \\
\mathbf{M}\end{array}$ & $\begin{array}{l}22 \\
10 \\
15\end{array}$ & $\begin{array}{l}26 \\
13 \\
18\end{array}$ & $\begin{array}{l}26 \\
13 \\
19\end{array}$ & $\begin{array}{l}27 \\
13 \\
19\end{array}$ & $\begin{array}{l}28 \\
13 \\
19\end{array}$ & $\begin{array}{l}27 \\
13 \\
19\end{array}$ & $\begin{array}{l}27 \\
14 \\
20\end{array}$ & $\begin{array}{l}27 \\
14 \\
19\end{array}$ & $\begin{array}{l}26 \\
12 \\
18\end{array}$ & $\begin{array}{l}26 \\
12 \\
18\end{array}$ & $\begin{array}{r}23 \\
9 \\
15\end{array}$ & $\begin{array}{r}22 \\
9 \\
14\end{array}$ & $\begin{array}{r}21 \\
8 \\
14\end{array}$ & $\begin{array}{r}20 \\
7 \\
13\end{array}$ & $\begin{array}{r}19 \\
7 \\
12\end{array}$ & $\begin{array}{r}19 \\
7 \\
12\end{array}$ \\
\hline
\end{tabular}

* Time in minutes. 


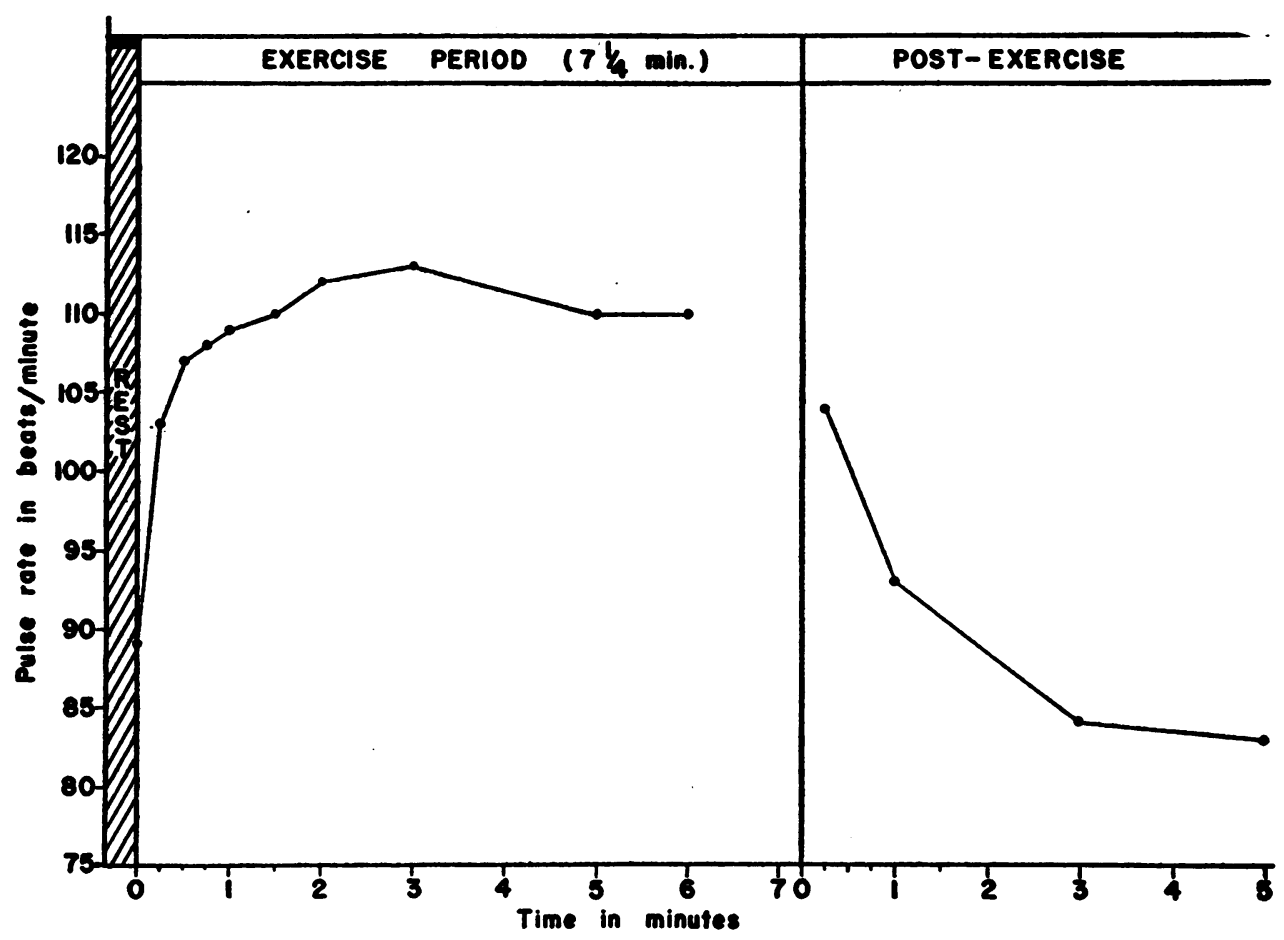

Fig.l. EFFeCt OF MILD SUPINE EXERCISE ON THE PULSE RATE. Average of 5 subjects

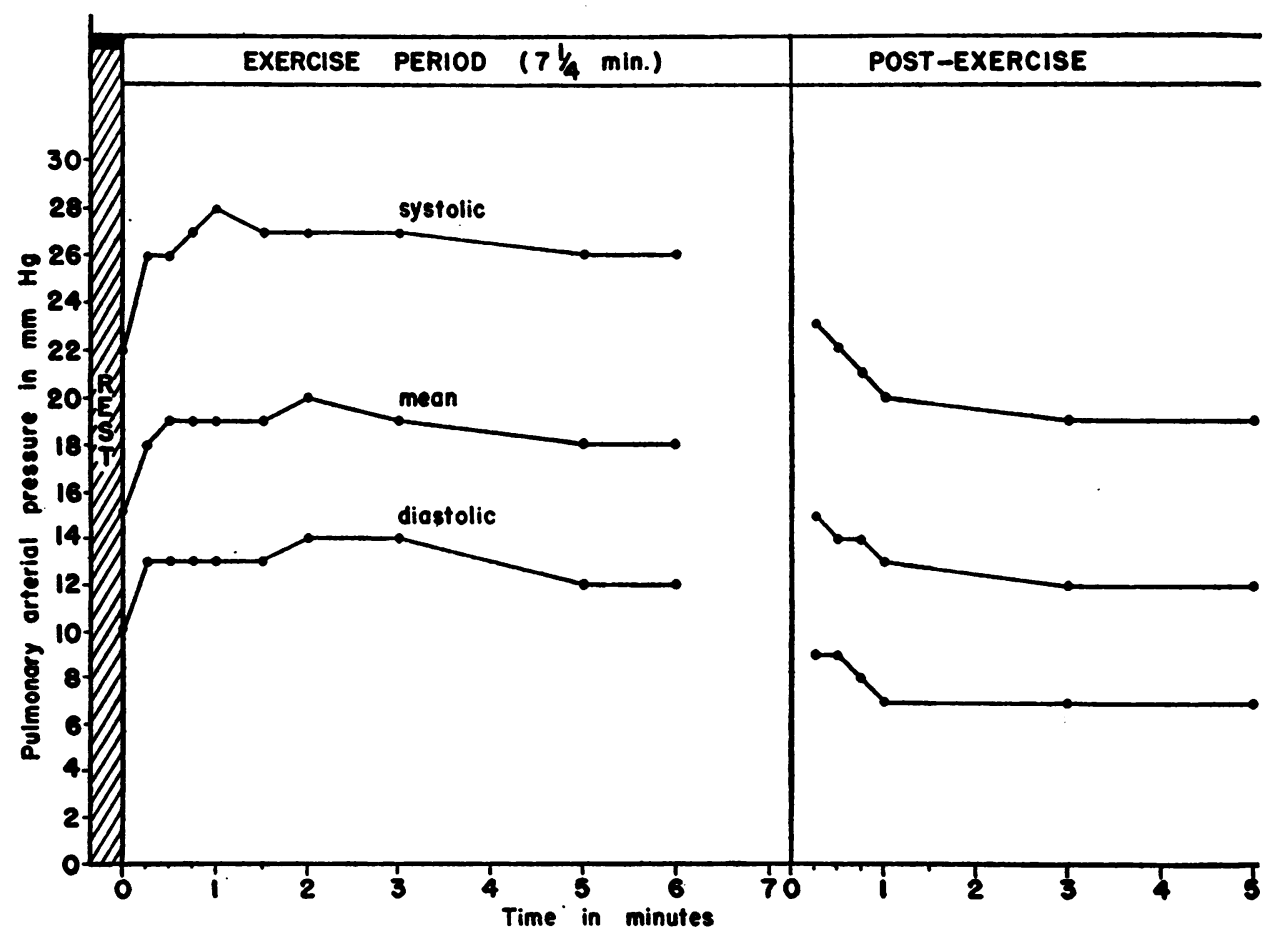

Fg. 2. EFFECT OF MILD SUPINE EXERCISE ON THE PULMONARY ARTERIAL PRESSURE. Average of 5 subjects. 
TABLE III

The effect of exercise on oxygen uptake and a comparison of values obtained by use of the standard formula and by use of an average respiratory exchange ratio correction

\begin{tabular}{|c|c|c|c|c|c|c|}
\hline \multirow[b]{2}{*}{ Subject } & \multicolumn{2}{|c|}{ Rest } & \multicolumn{2}{|c|}{$\begin{array}{l}3.6 \text { minutes } \\
\text { of exercise }\end{array}$} & \multicolumn{2}{|c|}{$\begin{array}{l}6.6 \text { minutes } \\
\text { of exercise }\end{array}$} \\
\hline & $\underset{\text { formula }}{\text { STy }}$ & $\begin{array}{c}\text { By } \\
\text { mean } \\
\text { factor } \\
1.007\end{array}$ & $\underset{\text { formula }}{\text { By }}$ & $\begin{array}{c}\text { By } \\
\text { mean } \\
\text { factor } \\
1.01\end{array}$ & $\underset{\text { STD }}{\text { By }}$ & $\begin{array}{c}\text { By } \\
\text { mean } \\
1.01\end{array}$ \\
\hline $\begin{array}{l}\text { MJB } \\
\text { MM } \\
\text { MMH } \\
\text { ELM } \\
\text { MES } \\
\text { AVG }\end{array}$ & $\begin{array}{l}238 * \\
234 \\
176 \\
170 \\
176 \\
199\end{array}$ & $\begin{array}{l}233 \\
232 \\
171 \\
168 \\
171 \\
195\end{array}$ & $\begin{array}{l}504 \\
527 \\
524 \\
512 \\
444 \\
502\end{array}$ & $\begin{array}{l}481 \\
513 \\
513 \\
509 \\
475 \\
498\end{array}$ & $\begin{array}{l}483 \\
510 \\
489 \\
479 \\
430 \\
478\end{array}$ & $\begin{array}{l}468 \\
508 \\
486 \\
482 \\
458 \\
480\end{array}$ \\
\hline
\end{tabular}

* All values for oxygen uptake are given as cc. per min.

diastolic pulmonary arterial pressures were 22,15 , and $10 \mathrm{~mm}$. $\mathrm{Hg}$, respectively. With exercise the same clear-cut pattern of response of the pulmonary arterial mean pressure was noted in every case (Figure 2). Within 15 seconds there was a sharp rise, the pressure reaching a peak value within 2 minutes and then remaining constant (two instances) or dropping slightly to a level which was higher than the resting control value (three instances). Following the abrupt cessation of exercise, there was a prompt fall in mean pressure to a level which was less than the resting control value. The systolic and diastolic pressures followed the same pattern, with only several minor exceptions.

\section{Oxygen uptake}

The oxygen uptake at rest varied from 108 to 128 cc. per min. per sq. $m$. of body surface area with a mean value of 120 . Assuming a respiratory exchange ratio of 0.85 , the basal metabolic rates were within normal limits in three subjects, and slightly low in two. The average basal metabolic rate was within normal limits. During exercise the oxygen uptake increased from 2 to 3 times. In each instance the oxygen uptake at 6.6 minutes of exercise was significantly less than that at 3.6 minutes.

Table III shows a comparison of oxygen uptake values obtained by substituting analytical results

TABLE IV

Some physiologic effects of exercise in normal human subjects

\begin{tabular}{|c|c|c|c|c|c|c|c|c|c|c|c|c|c|c|c|}
\hline \multirow[b]{2}{*}{ Subject } & \multicolumn{3}{|c|}{$\begin{array}{l}\text { Arterio-venous } \\
\text { oxygen difference } \\
(c c . / 100 \text { cc.) }\end{array}$} & & \multicolumn{3}{|c|}{$\begin{array}{l}\text { Cardiac output and } \\
\text { cardiac index } \\
\left(L . / \operatorname{min.} / m^{2} B S A\right)\end{array}$} & & \multicolumn{3}{|c|}{$\begin{array}{l}\text { Pulse rate } \\
\text { (beats/min.) }\end{array}$} & & \multicolumn{3}{|c|}{$\begin{array}{l}\text { Stroke output } \\
\text { and index } \\
(c c . / \text { beat and } \\
\left.\text { cc./beat } / \mathrm{m}^{2} B S A\right)\end{array}$} \\
\hline & Rest & $\begin{array}{c}3.6 \\
m i n .\end{array}$ & $\begin{array}{c}6.6 \\
\text { min. }\end{array}$ & & Rest & $\begin{array}{c}3.6 \\
\text { min. }\end{array}$ & $\begin{array}{c}6.6 \\
\text { mix. }\end{array}$ & & Rest & $\begin{array}{c}3.6 \\
m i n\end{array}$ & $\begin{array}{c}6.6 \\
\min .\end{array}$ & & Rest & $\begin{array}{c}3.6 \\
\min .\end{array}$ & $\begin{array}{c}6.6 \\
\min .\end{array}$ \\
\hline MJB & 4.20 & 6.75 & 6.60 & & $\begin{array}{l}5.73 \\
3.00\end{array}$ & $\begin{array}{l}7.47 \\
3.91\end{array}$ & $\begin{array}{l}7.32 \\
3.83\end{array}$ & & 95 & 108 & 110 & & $\begin{array}{l}60 \\
31\end{array}$ & $\begin{array}{l}69 \\
36\end{array}$ & $\begin{array}{l}66 \\
35\end{array}$ \\
\hline $\mathbf{M M}$ & 4.32 & 6.70 & 6.35 & & $\begin{array}{l}5.45 \\
2.98\end{array}$ & $\begin{array}{l}7.86 \\
4.30\end{array}$ & $\begin{array}{l}8.04 \\
4.39\end{array}$ & & 71 & 98 & 94 & & $\begin{array}{l}77 \\
42\end{array}$ & $\begin{array}{l}80 \\
44\end{array}$ & $\begin{array}{l}85 \\
46\end{array}$ \\
\hline $\mathbf{M M H}$ & 3.82 & 6.80 & 6.35 & & $\begin{array}{l}4.60 \\
3.22\end{array}$ & $\begin{array}{l}7.71 \\
5.39\end{array}$ & $\begin{array}{l}7.70 \\
5.38\end{array}$ & & 95 & 125 & 126 & & $\begin{array}{l}48 \\
34\end{array}$ & $\begin{array}{l}62 \\
43\end{array}$ & $\begin{array}{l}61 \\
43\end{array}$ \\
\hline ELM & 4.01 & 7.23 & 7.36 & & $\begin{array}{l}4.22 \\
2.68\end{array}$ & $\begin{array}{l}7.08 \\
4.48\end{array}$ & $\begin{array}{l}6.51 \\
4.12\end{array}$ & & 100 & 115 & 109 & & $\begin{array}{l}42 \\
27\end{array}$ & $\begin{array}{l}62 \\
39\end{array}$ & $\begin{array}{l}60 \\
38\end{array}$ \\
\hline MES & 3.88 & 7.85 & 7.65 & & $\begin{array}{l}4.54 \\
2.99\end{array}$ & $\begin{array}{l}5.66 \\
3.72\end{array}$ & $\begin{array}{l}5.62 \\
3.70\end{array}$ & & 85 & 117 & 117 & & $\begin{array}{l}53 \\
35\end{array}$ & $\begin{array}{l}48 \\
32\end{array}$ & $\begin{array}{l}48 \\
32\end{array}$ \\
\hline \multirow[t]{2}{*}{ AVG } & 4.05 & 7.07 & 6.86 & & $\begin{array}{l}4.91 \\
2.97\end{array}$ & $\begin{array}{l}7.16 \\
4.36\end{array}$ & $\begin{array}{l}7.04 \\
4.28\end{array}$ & & 89 & 113 & 110 & & $\begin{array}{l}56 \\
34\end{array}$ & $\begin{array}{l}64 \\
39\end{array}$ & $\begin{array}{l}64 \\
39\end{array}$ \\
\hline & \multicolumn{4}{|c|}{$\begin{array}{c}\text { Minute volume of breathing } \\
\text { (liters) }\end{array}$} & \multicolumn{5}{|c|}{$\begin{array}{c}\text { Oxygen uptake } \\
\left(c c . / m i n . / m^{2} B S A\right)\end{array}$} & & & \multicolumn{4}{|c|}{$\begin{array}{l}\text { Ventilation } \\
\text { equivalent }\end{array}$} \\
\hline Subject & \multicolumn{2}{|c|}{ Reat } & $\begin{array}{c}3.6 \\
\min .\end{array}$ & $\begin{array}{c}6.6 \\
\min .\end{array}$ & \multicolumn{3}{|c|}{ Rest } & $\begin{array}{c}3.6 \\
\text { min. }\end{array}$ & $\begin{array}{c}6.6 \\
\text { min. }\end{array}$ & & & Rest & $\begin{array}{l}3.6 \\
\text { min. }\end{array}$ & & $\begin{array}{c}6.6 \\
\min .\end{array}$ \\
\hline $\begin{array}{l}\text { MJB } \\
\text { MM } \\
\text { MMH } \\
\text { ELM } \\
\text { MES } \\
\text { AVG }\end{array}$ & \multicolumn{2}{|c|}{$\begin{array}{l}5.24 \\
5.02 \\
3.26 \\
3.44 \\
3.22 \\
4.04\end{array}$} & $\begin{array}{l}7.92 \\
8.50 \\
8.58 \\
8.75 \\
8.32 \\
8.41\end{array}$ & $\begin{array}{l}8.40 \\
9.44 \\
8.70 \\
8.51 \\
6.88 \\
8.39\end{array}$ & \multicolumn{3}{|c|}{$\begin{array}{l}125 \\
128 \\
123 \\
108 \\
116 \\
120\end{array}$} & $\begin{array}{l}264 \\
288 \\
366 \\
324 \\
292 \\
307\end{array}$ & $\begin{array}{l}253 \\
279 \\
342 \\
303 \\
283 \\
292\end{array}$ & & & $\begin{array}{l}2.20 \\
2.14 \\
1.85 \\
2.02 \\
1.83 \\
2.01\end{array}$ & \multicolumn{2}{|c|}{$\begin{array}{l}1.57 \\
1.61 \\
1.64 \\
1.71 \\
1.87 \\
1.68\end{array}$} & $\begin{array}{l}1.74 \\
1.85 \\
1.78 \\
1.78 \\
1.60 \\
1.75\end{array}$ \\
\hline
\end{tabular}


for carbon dioxide and oxygen concentrations in expired gas in the standard formula (9), and obtained by the use of an average respiratory exchange ratio correction (3). According to Dexter, Whittenberger, Haynes, Goodale, Gorlin, and Sawyer (3) it is not necessary to determine the carbon dioxide concentration in expired gas in order to obtain the oxygen uptake. They used a mean correction factor of 1.007 for converting expired volume to inspired volume at rest, and a factor of 1.01 for exercise. The volume of oxygen inspired was therefore calculated as percentage inspired oxygen $\times$ volume of expired gas $\times 1.007$ or 1.01. There is a remarkable similarity of the corresponding individual values and averages for rest. For exercise, there are several discrepancies ; however, the average values show excellent agreement.

\section{Arterial blood oxygen saturation}

The resting arterial oxygen saturations varied from 92 per cent to 96 per cent with a mean of 94 per cent. Samples collected at 3.6 minutes of exercise showed a slight increase in every instance. The mean arterial blood oxygen saturation at 3.6 minutes of exercise was 95 per cent.

Several factors influence the arterial oxygen saturation during exercise. Those tending to decrease it are the increased rate of pulmonary capillary flow, and the decreased venous saturation, while that tending to increase it is the increased respiratory surface area with its associated improvement of the ventilation-perfusion relationship. The latter has the effect of decreasing the slight venous admixture which is normally present. Hyperventilation, if present, would represent a second factor tending to increase arterial oxygen saturation through increased alveolar oxygen pressure. Either or both of these factors tending to increase arterial saturation could have been operative in our subjects.

\section{Arterio-venous oxygen difference}

The resting arterio-venous oxygen differences varied from 3.82 to 4.32 volumes per cent, with a mean of 4.05 (Table IV). At 3.6 minutes of exercise the arterio-venous oxygen difference had increased in every instance (mean 7.07 volumes per cent). The values for 6.6 minutes of exercise tend to be slightly less than those for 3.6 minutes.

The mean value of 4.05 volumes per cent for arterio-venous oxygen difference at rest, compares well with values previously reported (1-3, $10,11)$. Our values have a very narrow range. With exercise the arterio-venous oxygen difference increased as did the cardiac output. The A-V difference exceeded 6 volumes per cent during exercise in every case.

\section{Cardiac output}

The resting cardiac output varied from 2.68 to 3.22 L. per min. per sq. m. of body surface area, with a mean of 2.97 (Table IV). At 3.6 minutes of exercise, the mean cardiac index had risen to 4.36 , and at 6.6 minutes the mean value was 4.28 , a difference which is not significant.

The mean value of 2.97 for resting cardiac index agrees well with published values $(12,13)$. This fact, together with the failure to find low values for A-V difference, would seem to indicate that anxiety did not greatly disturb the resting circulatory dynamics of our subjects (10). However, the fact that three of the five subjects had definitely elevated resting pulse rates, indicates some degree of anxiety.

\section{Pulse rate and stroke output}

The resting pulse rate varied from 71 to 100 beats per min., with a mean of 89 (Table IV). At 3.6 minutes of exercise the mean pulse rate had risen to 113 , and at 6.6 minutes it was 110 , a decrease which is not significant. The mean pattern of response of the pulse rate to exercise (Figure 1) exhibits a striking similarity to that of the pulmonary arterial mean pressure (Figure 2). This pattern may be described as follows : a prompt rise in pulse rate following the abrupt start of exercise, the achievement of a steady state level, and a prompt fall following the abrupt cessation of exercise to a level lower than the resting control value.

The resting stroke output varied from 27 to 42 cc. per beat per sq. m. of body surface area, with a mean of 34 (Table IV). At 3.6 minutes of exercise the mean stroke index had risen to $39 \mathrm{cc}$. per beat per sq. m., but at 6.6 minutes there had been no further appreciable change in any case, the mean value having remained 39 . 
In:three instances the pulse rate increased relatively more than the stroke output, in one (ELM) the stroke output increased relatively more than the pulse rate, and in one (MES) the stroke output diminished slightly as the pulse rate increased. The response of ELM may be explained by the fact that this subject had the highest resting pulse rate and the lowest resting stroke output, so that during adaptation to exercise the stroke output changed relatively more. In the case of MES it would seem that in response to exercise an excessive tachycardia resulted in an actual decrease of stroke output. As will be pointed out later, the same subject (MES) responded to exercise with excessive hyperventilation.

\section{Minute volume of breathing and ventilation equivalent}

The resting minute volume of breathing varied from 3.22 to 5.24 liters (STPD), with a mean value of 4.04 (Table IV). At 3.6 minutes of exercise, the mean value had slightly more than doubled ( $8.41 \mathrm{~L}$. per min.), and the individual values were all within 0.85 liter of each other. As exercise continued, the minute volume remained quite constant in two cases, rose slightly in two cases, and fell somewhat in one case (MES).

The resting ventilation equivalent varied from 1.83 to 2.20 with a mean value of 2.01 . At 3.6 minutes of exercise, the ventilation equivalent had decreased in every instance except one (MES). All values for 6.6 minutes of exercise showed a slight increase (except MES), which in no instance reached the resting level. This increase reflects the uniform drop in oxygen uptake, and the unchanged or increased minute volume of breathing between 3.6 and 6.6 minutes of exercise. Subject MES responded to exercise with excessive hyperventilation, as shown by an initial increase of ventilation equivalent and respiratory exchange ratio. As the hyperventilation subsided from 3.6 to 6.6 minutes of exercise, the ventilation equivalent also diminished; however, the fact that the respiratory exchange ratio was still high at 6.6 minutes is evidence for persistent psychogenic hyperventilation.

The decrease in ventilation equivalent which occurs during exercise in normal subjects has been emphasized by Baldwin, Cournand, and Richards (14). Other workers (15) have noted an initial decrease, followed by a slow increase in ventilation equivalent as the steady state of exercise was approached. They also pointed out that this slow increase in ventilation equivalent was the result of diminishing oxygen uptake and the tendency of minute volume slightly to rise.

\section{DISCUSSION}

Our values for resting pulmonary arterial systolic, mean, and diastolic pressures are in close agreement with previously published values (1-3, $12,13)$. In each of our five subjects the same pattern of response of the pulmonary arterial mean pressure to exercise was found: a prompt rise in pressure following the abrupt start of exercise, the achievement of a steady state level which was higher than the resting control value, and a prompt fall in pressure, following the abrupt cessation of exercise, to a level lower than the resting control value. This pattern of response to exercise has not been previously described in human subjects. On the contrary, it has been stated that the pulmonary arterial pressure does not rise appreciably with mild exercise in subjects with normal cardiorespiratory systems (1-3).

Euler and Liljestrand (16), working with anesthetized cats, noted a moderate rise of pulmonary arterial pressure during exercise in four of five experiments. The pattern of change which these workers found is identical with that which we have described in this paper.

Hickam and Cargill studied the effects of exercise on normal subjects in the supine position, and concluded that the normal pulmonary vascular bed can accommodate a large increase in the rate of blood flow with little or no increase in pulmonary arterial mean pressure (1). The work rates of their subjects were all comparable to those of ours. Their data show that in seven exercise studies on seven subjects a pressure increase was recorded in five instances $(2,5,2,2$, and $2 \mathrm{~mm}$. $\mathrm{Hg}$, respectively) and a decrease in two instances ( 1 and $2 \mathrm{~mm}$. $\mathrm{Hg}$, respectively). Dexter and his coworkers, who also studied the effects of exercise on normal subjects in the supine position, concluded that only at work rates corresponding to oxygen uptakes exceeding $400 \mathrm{cc}$. per min. per sq. $\mathrm{m}$. of body surface area does a rise of pulmonary arterial pressure occur (3). These authors stated that exer- 
cise, producing an oxygen uptake of less than 400 cc. per min. per sq. m., was accompanied by inconstant changes of pressure in the pulmonary artery. Four of their subjects exercised at work rates comparable to those of ours, resulting in an increase from an average of 133 at rest to $288 \mathrm{cc}$. per min. per sq. m. during exercise, compared to an increase for our five subjects from an average of 120 to 307 . Their data for these four subjects show that the pulmonary arterial mean pressure increased $4 \mathrm{~mm}$. $\mathrm{Hg}$, which is an increase of approximately one-third over their average resting control mean pressure of $13 \mathrm{~mm}$. Hg. These authors $(1,3)$, using a cautious criterion for elevation of the pulmonary arterial pressure, hesitated justifiably to conclude that the increases which they observed were significant. Although the pressure changes which we observed are of the same order of magnitude as those referred to above, the changes reported in the present study are highly significant because of the serial nature of the observations.

It should be emphasized that our study, and those of Dexter and his associates, and Hickam and Cargill were made on subjects exercising in the supine position. Man is almost unique among mammals in his preference for the supine rather than the prone posture when recumbent. The center of mass of the left ventricle is 7 to $10 \mathrm{~cm}$. higher, in relation to the center of mass of the lungs, in the supine position than when one is erect. From this consideration alone, it is obvious that the supine position is a very special posture, and that our conclusions based on studies of subjects exercising in the supine position would not necessarily apply to exercise in the erect position.

Riley, Himmelstein, Motley, Weiner, and Cournand (2) reported the effects of exercise in the sitting position on three normal subjects. In five trials on three subjects exercising on a bicycle ergometer, the pulmonary arterial mean pressure decreased four times $(7,5,1$, and $5 \mathrm{~mm}$. $\mathrm{Hg}$, respectively) and increased once (1 $\mathrm{mm}$. $\mathrm{Hg}$ ). These results are in contrast to those obtained during exercise in the supine position; however, it would seem important to confirm these observations through further study.

The pulmonary arterial pressure rise observed during supine exercise could be due to either or both of the following factors: increased cardiac output or increased total pulmonary resistance. Calculations from our data for 6.6 minutes of exercise indicate that the observed pulmonary arterial mean pressure rises were completely accounted for by the increases in cardiac output in every case except one (MJB), where an increase of calculated total pulmonary resistance made a slight contribution.

Although the cardiac output during the first minute of exercise is unknown, it is likely that the prompt pulmonary arterial pressure rise following the abrupt start of exercise is due to increased cardiac output. An increase of total pulmonary resistance at that time seems unlikely. The finding of increases of cardiac output which are relatively greater than the pulmonary arterial pressure increases during exercise indicates a decreased total pulmonary resistance. This was definitely the case in three of our five subjects (MMH, ELM, and MES). In these three subjects, the pulmonary arterial pressure rose during exercise to a peak value, and then descended to a steady state level. The two subjects in whom a significant decrease of total pulmonary resistance during exercise did not occur ( $M J B$ and $M M$ ), failed to show this descent from a peak value. The rate of decline of the pulmonary arterial mean pressure from its peak to a plateau may be an index of the rate at which vascular dilatation occurs, and the prompt fall following the abrupt cessation of exercise to a level lower than the resting control value suggests that the cardiac output decreases more rapidly than the pulmonary vascular bed contracts.

It has been suggested $(1,2)$ that this fall of total pulmonary resistance in association with increased cardiac output indicates the opening of new vascular channels or the further widening of those already open. The possibility was considered that a rise of left atrial pressure might mask a decrease in pulmonary vascular resistance. If the pulmonary "capillary" pressure accurately reflects the left atrial pressure, the data of Dexter and his associates (3) would suggest that the left atrial pressure may rise during mild, supine exercise in normal human subjects.

Comparisons have been made of the pressureflow relationships in the post-pneumonectomy patient with those in the exercising normal subject. Our finding, that mild supine exercise results in 
an increase of pulmonary arterial pressure, suggests that conditions in the resting, supine postpneumonectomy patient are different from those in the exercising normal subject. Apparently, the acute experiment is not strictly comparable to the post-pneumonectomy situation.

With the degree of exercise employed in our study, the oxygen uptake increased from two to three times. Although the rate of oxygen uptake is an index of the work rate, several factors render this index approximate: failure to achieve the steady state, qualitative variations in protein metabolism, and the varying heat equivalent of a unit volume of oxygen depending upon the ratio of protein, fat, and carbohydrate being consumed by the body. Considering both the values for oxygen uptake during exercise and the calculated rate of performing external work, the exercise done by our subjects must be considered mild.

The use of an average respiratory exchange ratio correction factor to obtain the oxygen uptake eliminates the necessity for determination of carbon dioxide in expired gas (3). Values for oxygen uptake at rest obtained by this method were in very close agreement with those obtained by use of the conventional formula (9). Values for oxygen uptake during exercise, however, showed several discrepancies. As expected, the 3.6 minute comparisons agreed less well than those for 6.6 minutes. This is due to the fact that before the steady state is approached, there is greater variability, and therefore unpredictability, of the respiratory exchange ratio than after achievement of a semi-steady state, when the ratio is more nearly equal to the metabolic respiratory quotient. In this connection, it should be noted that Lukas and Dotter found the respiratory exchange ratio of their mitral stenosis patients to be too variable, particularly during exercise, to permit the use of mean correction factors for adjusting expired to inspired air volume (17).

The observed decrease of oxygen uptake from 3.6 to 6.6 minutes of exercise ( 5 per cent) reflects the gradual achievement of the steady state. Other workers (15) have also found a decrease of 5 per cent after the third minute of exercise. The difficulty of achieving a steady state during exercise, and its importance for the interpretation of data obtained during exercise, have been stressed (18). The necessity for having achieved the steady state before determining cardiac output by the Fick principle has recently been reemphasized (19). Significant changes of oxygen uptake, arterio-venous oxygen difference, and respiratory exchange ratio for expired gas between 3.6 and 6.6 minutes of exercise, indicate, as was anticipated, that our subjects had not achieved the steady state by 3.6 minutes. The length of time required to attain the steady state during exercise would be even greater for more intense work rates, or for subjects with cardiopulmonary disease.

Increased utilization of oxygen by the exercising tissues precedes the circulatory and respiratory adjustments necessary for increased oxygen supply. Bruce and his associates (15) related the peak value for oxygen uptake, which occurs by the third minute of exercise, to the increasing A-V oxygen difference, the result of diminishing venous blood oxygen content, due, in turn, to the lagging increase of cardiac output. As exercise continues and the steady state is approached, oxygen delivery to the tissues comes into equilibrium with oxygen utilization. Thus, while work rate and therefore tissue oxygen utilization remain constant, delivery and uptake of oxygen slowly decline from their peak values, A-V oxygen difference slowly decreases, and cardiac output remains relatively constant.

From the foregoing it is apparent that the Fick principle was not entirely applicable to the determination of cardiac output in our subjects at 3.6 minutes of exercise. The 3.6 minute values for cardiac output are subject to an error, which from our data is unpredictable both as to direction and magnitude. It would appear, however, from the fact that the 3.6 minute values were very nearly equal to the values at 6.6 minutes, that the $3.6 \mathrm{~min}$ ute values as calculated were slightly in excess of the true cardiac outputs.

\section{SUMMARY}

1. Data regarding the circulatory and respiratory adaptation to exercise of five normal adults are presented and their significance is discussed.

2. The pulmonary arterial mean pressure responded in each instance with a prompt rise following the abrupt start of exercise, the achievement of a steady state level which was higher than the resting control value, and a prompt fall fol- 
lowing the abrupt cessation of exercise, to a level lower than the resting control value.

3. The difficulty with which a steady state of the respiration and circulation is reached during exercise, and the necessity for having achieved the steady state prior to determination of cardiac output by the Fick principle, are emphasized.

\section{REFERENCES}

1. Hickam, J. B., and Cargill, W. H., Effect of exercise on cardiac output and pulmonary arterial pressure in normal persons and in patients with cardiovascular disease and pulmonary emphysema. J. Clin. Invest., 1948, 27, 10.

2. Riley, R. L., Himmelstein, A., Motley, H. L., Weiner, H. M., and Cournand, A., Studies of the pulmonary circulation at rest and during exercise in normal individuals and in patients with chronic pulmonary disease. Am. J. Physiol., 1948, 152, 372.

3. Dexter, L., Whittenberger, J. L., Haynes, F. W., Goodale, W. T., Gorlin, R., and Sawyer, C. G., Effect of exercise on circulatory dynamics of normal individuals.. J. Applied Physiol., 1951, 3, 439.

4. Warren, J. V., Determination of cardiac output in man by right heart catheterization in Methods in Medical Research. Vol. 1, ed. by Potter, V. R., Chicago, Yearbook Publishers, 1948, p. 224.

5. Bronfin, G. J., Dressler, S. H., and Ravin, A., An apparatus for exercising a patient in the recumbent position. J. Lab. \& Clin. Med., 1950, 35, 317.

6. Roughton, F. J. W., and Scholander, P. F., Microgasometric estimation of the blood gases. I. Oxygen. J. Biol. Chem., 1943, 148, 541.

7. Balchum, O. J., Hartman, S. A., Slonim, N. B., Dressler, S. H., and Ravin, A., The permeability of the Douglas-type bag to respiratory gases. J. Lab. \& Clin. Med., 1953, 41, 268.

8. Scholander, P. F., Analyzer for accurate estimation of respiratory gases in one-half cubic centimeter samples. J. Biol. Chem., 1947, 167, 235.
9. Pappenheimer, J. R., et al., Standardization of definitions and symbols in respiratory physiology. Federation Proc., 1950, 9, 602.

10. Stead, E. A., Jr., Warren, J. V., Merrill, A. J., and Brannon, E. S., The cardiac output in male subjects as measured by the technique of right atrial catheterization. Normal values with observations on the effect of anxiety and tilting. J. Clin. Invest., 1945, 24, 326.

11. Cournand, A., Riley, R. L., Breed, E. S., Baldwin, E. deF., and Richards, D. W., Jr., Measurement of cardiac output in man using the technique of catheterization of the right auricle or ventricle. J. Clin. Invest., 1945, 24, 106.

12. Cournand, A., Recent observations on the dynamics of the pulmonary circulation. Bull. New York Acad. Med., 1947, $23,27$.

13. Cournand, A., Some aspects of the pulmonary circulation in normal man and in chronic cardiopulmonary diseases. Circulation, 1950, 2, 641.

14. Baldwin, E. deF., Cournand, A., and Richards, D. W., Jr., Pulmonary insufficiency. I. Physiological classification, clinical methods of analysis, standard values in normal subjects. Medicine, 1948, 27, 243.

15. Bruce, R. A., Lovejoy, F. W., Jr., Pearson, R., Yu, P. N. G., Brothers, G. B., and Velasquez, T., Normal respiratory and circulatory pathways of adaptation in exercise. J. Clin. Invest., 1949, 28, 1423.

16. Euler, U. S. v., and Liljestrand, G., Observations on the pulmonary arterial blood pressure in the cat. Acta physiol. Scandinav., 1946, 12, 301.

17. Lukas, D. S., and Dotter, C. T., Modifications of the pulmonary circulation in mitral stenosis. Am. J. Med., 1952, 12, 639.

18. Bock, A. V., Vancaulaert, C., Dill, D. B., Fölling, A., and Hurxthal, L. M., Studies in muscular activity. IV. The "steady state" and the respiratory quotient during work. J. Physiol., 1928, 66, 162.

19. Fishman, A. P., McClement, J., Himmelstein, A., and Cournand, A., Effects of acute anoxia on the circulation and respiration in patients with chronic pulmonary disease studied during the "steady state." J. Clin. Invest., 1952, 31, 770. 